\title{
Working
}

Paper 
Monetary Policy Transmission in the GCC Countries

Raphael Espinoza and Ananthakrishnan Prasad 
This page intentionally left blank 


\title{
IMF Working Paper
}

Middle East and Central Asia Department

\section{Monetary Policy Transmission in the GCC Countries}

\section{Prepared by Raphael Espinoza and Ananthakrishnan Prasad}

Authorized for distribution by David O. Robinson

May 2012

\section{This Working Paper should not be reported as representing the views of the IMF.} The views expressed in this Working Paper are those of the author(s) and do not necessarily represent those of the IMF or IMF policy. Working Papers describe research in progress by the author(s) and are published to elicit comments and to further debate.

\begin{abstract}
The GCC countries maintain a policy of open capital accounts and a pegged (or nearlypegged) exchange rate, thereby reducing their freedom to run an independent monetary policy. This paper shows, however, that the pass-through of policy rates to retail rates is on the low side, reflecting the shallowness of money markets and the manner in which GCC central banks operate. In addition to policy rates, the GCC monetary authorities use reserve requirements, loan-to-deposit ratios, and other macroprudential tools to affect liquidity and credit. Nonetheless, a panel vector auto regression model suggests that U.S. monetary policy has a strong and statistically significant impact on broad money, non-oil activity, and inflation in the GCC region. Unanticipated shocks to broad money also affect prices but do not stimulate growth. Continued efforts to develop the domestic financial markets will increase interest rate pass-through and strengthen monetary policy transmission.
\end{abstract}

JEL Classification Numbers:E52; E58

Keywords: Transmission mechanism; Fixed exchange rate regime; interest rate pass-through; panel VAR

Author's E-Mail Address: respinoza@imf.org; aprasad@imf.org 
I. Introduction $\underline{3}$

II. Behavior of GCC Monetary Policy vis-à-vis the United States.................................... 4

III. Interest Rate Pass-through .............................................................................. 7

IV. Monetary Transmission in the GCC -A Panel VAR Approach ....................................15

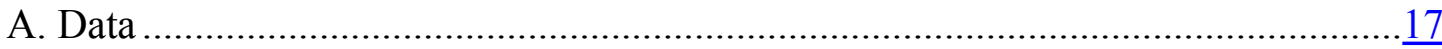

B. Annual Data Panel VAR …….............................................................. $\frac{17}{20}$

C. Quarterly Data Panel VAR...................................................................... $\frac{20}{21}$

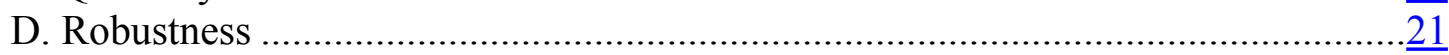

V. Summary and Policy Implications ................................................................

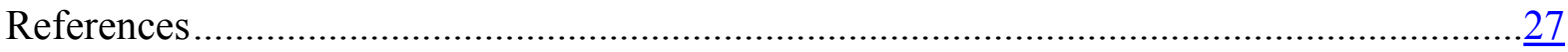

Tables

1. Co-integrating Vector ...................................................................................... 13

2. Forecast Error Variance Contribution.................................................................. $\frac{15}{18}$

3. Correlation Matrix of Innovations ................................................................... 18

4. OLS Estimates of the Annual VAR ...................................................................

Figures

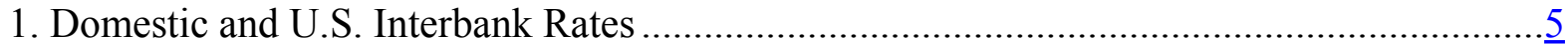

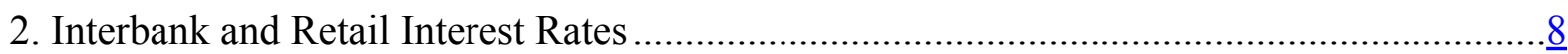

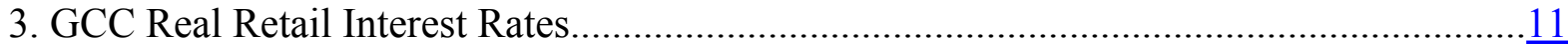

4. Dynamic Adjustment of Deposit and Lending Rates to Shocks in the Interbank Rates......14

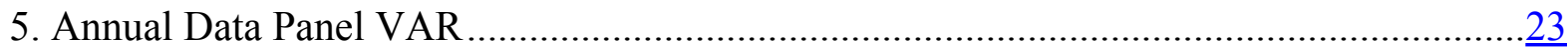

6. Quarterly Data Panel VAR ................................................................................24

7. Robustness to Country Composition ............................................................................25

8. Robustness to VAR Specification Composition ...................................................... 


\section{INTRODUCTION ${ }^{1}$}

The dollar peg provides the nominal anchor for monetary policy for all GCC countries (other than Kuwait), but the monetary authorities in the region employ a variety of instruments to influence liquidity conditions. ${ }^{2}$ As the peg to the U.S. dollar restricts the independence of monetary policy, macroeconomic management mostly relies on fiscal policy, prudential regulation, and various controls to achieve the desired balance between price stability and growth. ${ }^{3}$

The pegged exchange rate regime provided certainty about future exchange rates and was overall successful in anchoring inflationary expectations at low levels. Nevertheless, the GCC monetary authorities conduct monetary policy and manage short-term liquidity conditions through open market operations and standing facilities, while using liquidity and reserve requirements, long-term government bonds, and macroprudential instruments to manage structural liquidity conditions. In light of the openness of the GCC capital accounts, it would be reasonable to assume these operations have a limited impact on interest rates, as we would

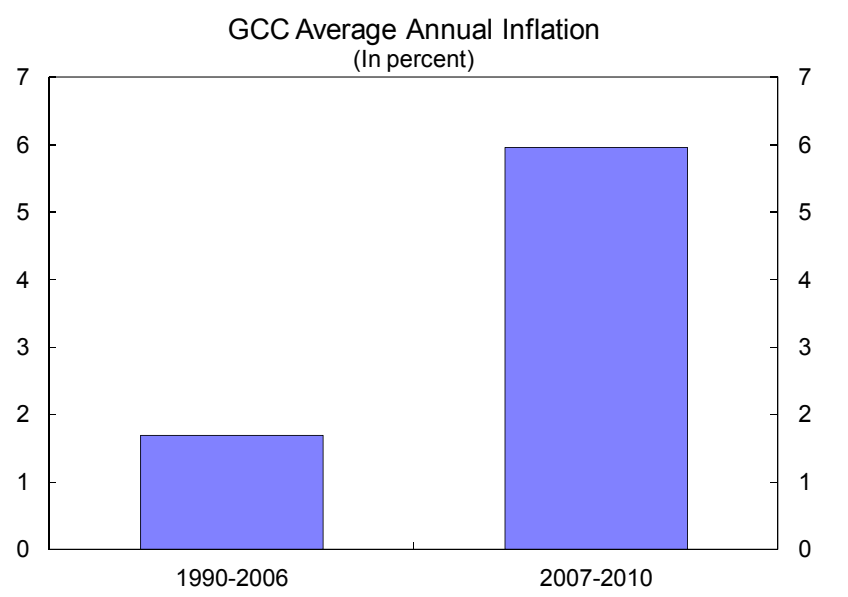
expect interest rates to converge quickly toward U.S. nominal interest rates. However, in several instances, interest rates in GCC countries have deviated vis-à-vis U.S. rates. ${ }^{4}$

This paper draws on past studies (Bova, 2012; Espinoza, Prasad, and Williams, 2011) to establish the behavior of GCC interbank interest rates with respect to the U.S. LIBOR rate, as a preliminary discussion on interest rate policy independence under the peg. It further estimates the degree of pass-through from policy rates to domestic deposit and lending rates, giving insights into the transmission mechanism as well as the structure of the banking sector. It also evaluates and distinguishes between the short- and long-term dynamics of adjustment through a co-integration analysis; and finally explores the channels of transmission of monetary policy,

\footnotetext{
${ }^{1}$ The authors wish to thank Zsofia Arvai, Samya Beidas-Strom, Ghada Fayad, May Khamis, Tobias Rasmussen, David Robinson, and Niklas Westelius for their helpful comments. Special thanks are due to the editor Kia Penso, Arthur Ribeiro and Renas Sidahmed for their research assistance and to Diana Kargbo-Sical and Carolina Parodi for their administrative assistance.

${ }^{2}$ In Kuwait, a dollar peg was in place from 2003 to May 2007, while a basket peg with undisclosed weights was in place before and after this period.

${ }^{3}$ Prasad and Khamis (2011) provides a detailed description of the monetary and prudential ratios in the GCC countries.

${ }^{4}$ For instance, several GCC countries delayed the reduction in domestic interest (they subsequently came down) because of domestic inflationary pressures.
} 
via monetary aggregates and economic activity, within a panel vector auto regression (VAR) framework.

Our analysis indicates that the GCC three-month interbank rates closely mirrored the U.S. interbank rates only in Bahrain and Saudi Arabia. In Kuwait, Oman, Qatar, and the United Arab Emirates, there were deviations to varying degrees, especially after the global crisis. In addition, the pass-through from local interbank rates to local deposit and lending rates is low. A cointegration analysis shows that the long-term relationship between interbank rates and bank lending and deposit rates is strongest for Bahrain and Kuwait, but the adjustment of retail rates to interbank rates is significantly lower than 1 , even in the long run.

Finally, a monetary VAR model, estimated using panel data for the GCC, suggests that there is a strong and statistically significant impact of U.S. monetary policy on broad money, non-oil activity, and inflation in the GCC region. The identification of U.S. monetary policy shocks is more convincing when data over the period 1980-1994 are used. Unanticipated changes to broad money (including those due to discretionary central bank policy) increase prices but have no significant effects on non-oil GDP.

\section{Behavior of GCC Monetary Policy Vis-À-VIS the United States}

Although the focus is on policy interventions, policy rates do not provide a full picture of the manner in which the GCC central banks intervene in the market, because monetary policy is conducted using a range of direct instruments. ${ }^{5}$ Therefore, the interbank rates tend to better reflect the outcome and intentions of monetary policy. Furthermore, the series for policy rates are not readily available over a long horizon, and this complicates the analysis. The use of interbank rates, however, raises problems of interpretation inasmuch it becomes difficult to distinguish whether changes in the rates are simply due to market dynamics (capital flows, interbank market conditions), or more specifically to monetary policy interventions (Bova, 2012).

For the study of the transmission of U.S. interest rates to GCC interest rates, this analysis uses the three-month local interbank rates for each GCC country as provided by the individual country sources. ${ }^{6}$ The series are monthly from January 2004 to January 2011. For the GCC countries, the three-month interbank rate (except for Oman, where the overnight rate was the only available rate), and for the United States, the three-month U.S.-Libor rate is used. The choice of a maturity of three months for the domestic interbank rates reduces the level of risk premium embodied in the differential, as this usually emerges in longer-term maturity (Chinn and Meredith 2004).

\footnotetext{
${ }^{5}$ These are specifically the central bank overnight rate for Bahrain; the repo and discount rate for Kuwait; the overnight central bank and certificates of deposit (CD) rates for Oman; the QCB lending and deposit rates for Qatar, the reverse repo for Saudi Arabia; and the CD rate for the UAE.

${ }^{6}$ Bova (2012) used the interbank rates provided by the Saudi Arabian Monetary Agency.
} 
A casual inspection of interest rate trends between January 2004 and January 2011 (Figure 1) indicates that the GCC three-month interbank rates have closely mirrored the U.S. rates in Bahrain and Saudi Arabia, but there were varying degrees of deviation in Kuwait, Qatar, Oman, and the United Arab Emirates, particularly since the onset of the global crisis in 2007. In Oman, domestic interest rates do not fully reflect the interest rate trends of the anchor currency, the U.S. dollar; a pattern of low domestic interest rates, in relation to comparable U.S. interest rates, has persisted throughout the sample period.

Figure 1. GCC: Domestic and U.S. Interbank Rates
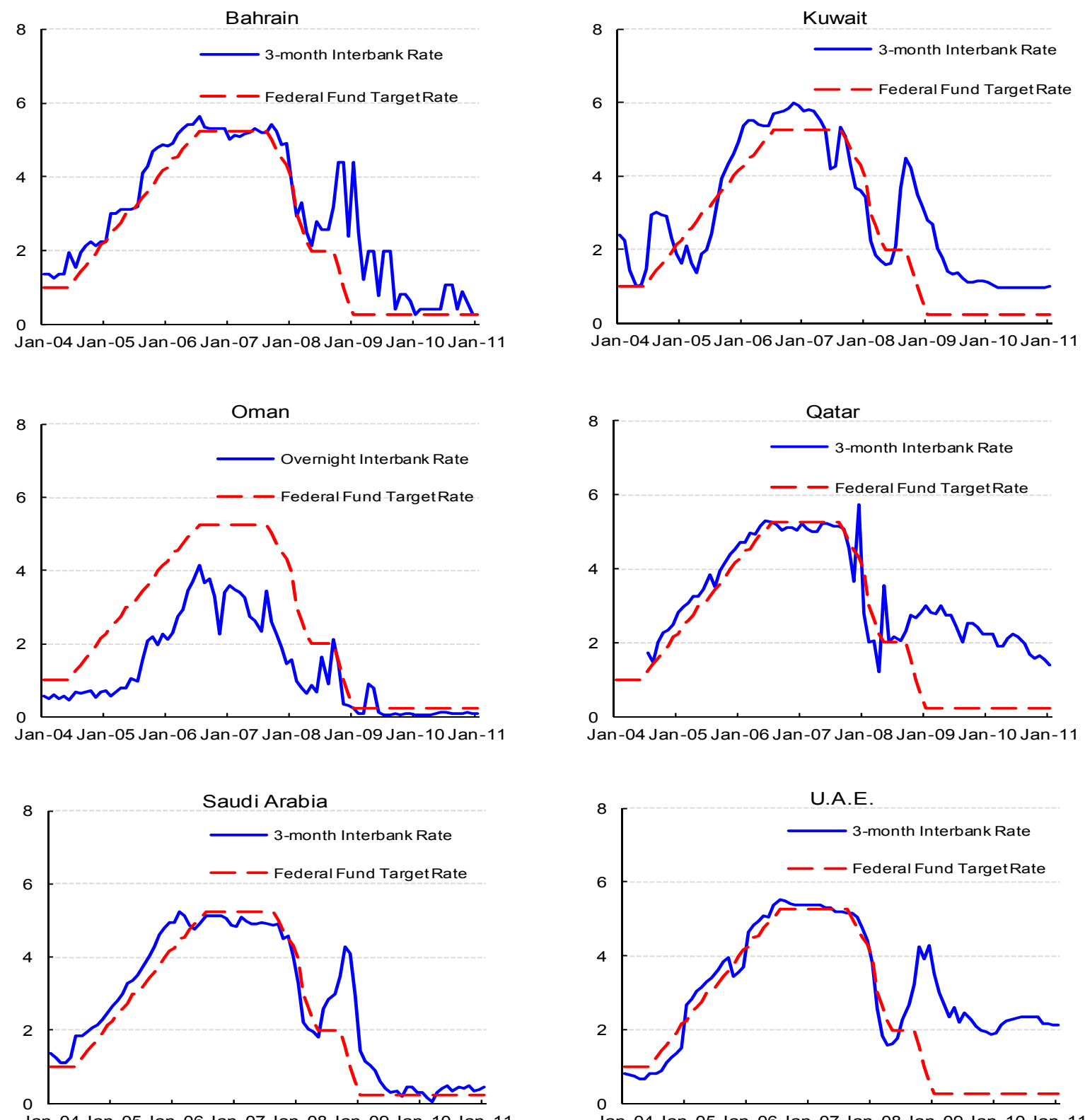

Jan-04 Jan-05 Jan-06 Jan-07 Jan-08 Jan-09 Jan-10 Jan-11

Jan-04 Jan-05 Jan-06 Jan-07 Jan-08 Jan-09 Jan-10 Jan-11 Source: Haver and country authorities. 
Bova (2012) cast light on the way the GCC rates have behaved with respect to the U.S.-Libor rate for the period from January 1993 to May 2009. They find that the GCC rates are all cointegrated with the U.S. rate, and that the long-run coefficient is very close to one, which constitutes an additional validation of the interest parity condition. ${ }^{7}$ Through a decomposition of the variance of the interbank rates and GMM estimates, the study also provides some evidence in support of the hypothesis that deviations from the US rate have been determined by monetary policy interventions. All in all, the deviations between the GCC rates and the U.S. rate, as reported in their study, are not large enough to undermine the validity of the fixed exchange rate regime. ${ }^{8}$

Bova (2012) also find that Kuwait and Oman have followed the U.S. monetary policy less closely. The currency basket in Kuwait allowed for more flexibility in the exchange rate and in monetary policy. In Oman, deviations from the U.S. rate have been possible because of the relatively stricter restrictions on capital movements in the banking system. Nevertheless deviations were confined to the short term, with adjustments taking one month on average. In the more recent period in the sample, however, the extent of the divergence was much higher and the adjustment took much longer, partly because GCC central banks were unwilling to follow U.S. monetary policy after Lehman's collapse, and partly because higher interest rates in the GCC could be maintained without attracting capital flows in the context of the global crisis.

Figure 1 also shows that the deviations were larger since 2009 in Qatar and in the United Arab Emirates. In Qatar, the central bank did not change its policy rates between September 2008 and August 2010, a period when the United States progressively reduced its federal funds rate to zero. In the United Arab Emirates, the domestic corporate sector debt problems in Dubai, and, in Kuwait, problems with investment companies, could have played a part in increasing the risk premia in the respective countries' local interbank markets.

\footnotetext{
${ }^{7}$ Due to lack of data on expected exchange rates, the study only tests for the validity of the covered interest parity condition. A co-integration relationship and an error correction model (ECM) are also estimated for the interest rate spreads in order to evaluate long- and-short run dynamics. Finally, the study carries out a decomposition of the variance of the interbank rates and GMM estimates to evaluate the relative impact of the U.S. rate and domestic variables - CPI inflation, the spot and forward exchange rate ratios, and the stock market index —on monetary policy.

${ }^{8}$ The speed at which each GCC rate adjusts to its long-run relationship with the U.S. rate can be estimated via an error correction model. Estimates indicate that the Bahraini rate is the quickest to adjust to deviations from the long-run relationship (less than two months), followed by Qatar (less than four months), Saudi Arabia (more than four months), and the United Arab Emirates (about six months). Kuwait and Oman have the slowest adjustment (about a year). For all economies except the United Arab Emirates, the speed of adjustment is estimated to have slowed in the years corresponding to the financial crisis.
} 
Interest rates have also converged within the GCC before 2008, and diverged during the crisis. Espinoza, Prasad, and Williams (2011) found some evidence of interest rate convergence using the widely used measure of beta-convergence (e.g. Baele et al., 2004), and estimated a half-life of two to five months. ${ }^{9}$ They also found the cross-sectional variation among interest rates in GCC countries to decline, notwithstanding a widening in this variance with the emergence of the global financial crisis.

\section{Interest Rate Pass-Through}

The response of market interest rates to policy rates can be quantified by estimating the interest rate pass-through. The pass-through of policy rates varies among countries and over different time periods. In some countries, deposit rates are stickier than lending rates while in others the reverse is true. For instance, in the Euro Area, overnight and three-month deposit rates with pass-through reaching at most 40 per cent, even in the long run. The low pass-through in the Euro Area can be attributed partly to the way these deposits are administered, and partly to the low elasticity of deposits to interest rates. In contrast to what was found for the Euro Area, Mizen and Hofmann (2002) found that, for the UK, passthrough from policy rates to deposit rates is larger than that for lending rates. In addition, pass-through may vary by types of loans. Pass-through to consumer lending rates is found to be the weakest, reflecting a variety of factors - weak competition, inelastic demand, asymmetric information, and credit rationing (Bondt, 2002; Bond et al. 2003). In the United States, credit card rates remain the stickiest. Pass-through was found at only 30 percent during the 1990s, albeit higher than the almost negligible level of the 1970s (Sellon, 2002). A more recent study (Kwapil and Scharler, 2006) compared the pass-through in deposit and lending rates in the United States and the euro area. Their study finds that for the United States, the long-run pass-through is complete for most categories of deposit rates and on average 0.57 for lending rates. In the euro area, the average long-run pass-through to deposit rates amounts to 0.32 , and the pass-through for the weighted average lending rates lies at 0.48 .

Evidence is inconclusive as to whether the response is symmetric to monetary policy signals. A few studies find an asymmetric response, i.e., the pass-through is quicker when monetary policy is tightened, and sluggish when monetary policy is eased (Sellon, 2002). Among the other key findings of the literature, competition increases pass-through, but mainly in deposit markets (Sander and Kleimeier, 2004). Market concentration (mergers) per se does not reduce the pass-through as long as the markets are contestable (Cottarelli and Kourelis, 1994).

\footnotetext{
${ }^{9}$ The first measure, beta-convergence, evaluates whether interest rates in countries with relatively high spreads have a tendency to decrease more rapidly than those in countries with low spreads. The second measure, sigmaconvergence, which draws from the growth literature, tests whether the cross-country standard deviation of interest rates had a declining trend.
} 
We estimate the pass-through from interbank rates over the period 2004-11, for both deposit and lending rates. For each country, the interbank rate is used as a proxy for the policy rate. Figure 2 presents the movements in interbank and deposit and lending rates in Bahrain, Kuwait, Oman, and Qatar. Data for lending rates and deposit rates were not available for Saudi Arabia and the United Arab Emirates, respectively.

Figure 2. GCC Interbank and Retail Interest Rates, 2004-11

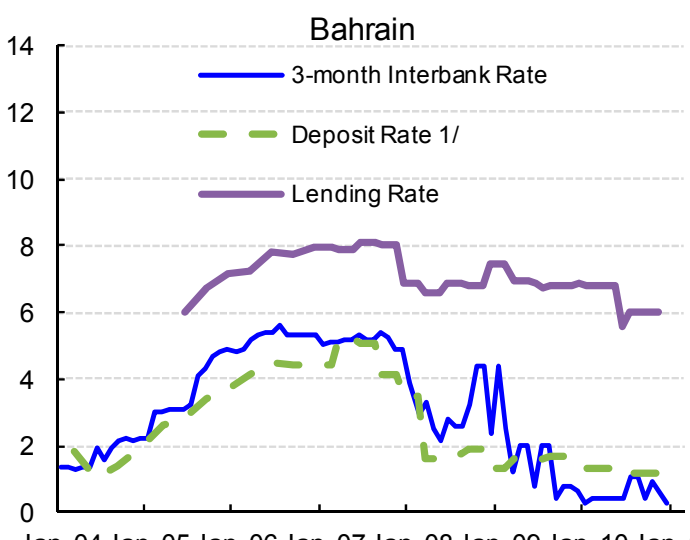

Jan-04 Jan-05 Jan-06 Jan-07 Jan-08 Jan-09 Jan-10 Jan-11

1/ Time deposit rate (3 months)

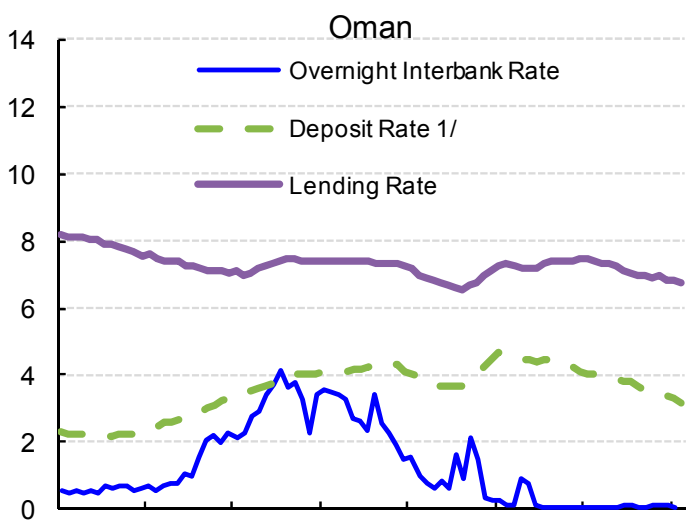

Jan-04 Jan-05 Jan-06 Jan-07 Jan-08 Jan-09 Jan-10 Jan-11

$1 /$ Time deposit rate (weighted average).

Sources: Haver Analytics; and country authorities.

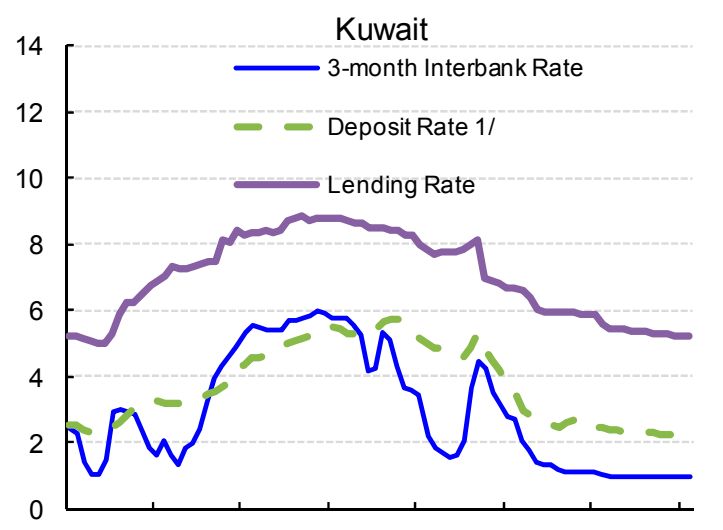

Jan-04 Jan-05 Jan-06 Jan-07 Jan-08 Jan-09 Jan-10 Jan-11

1/Weighted average.

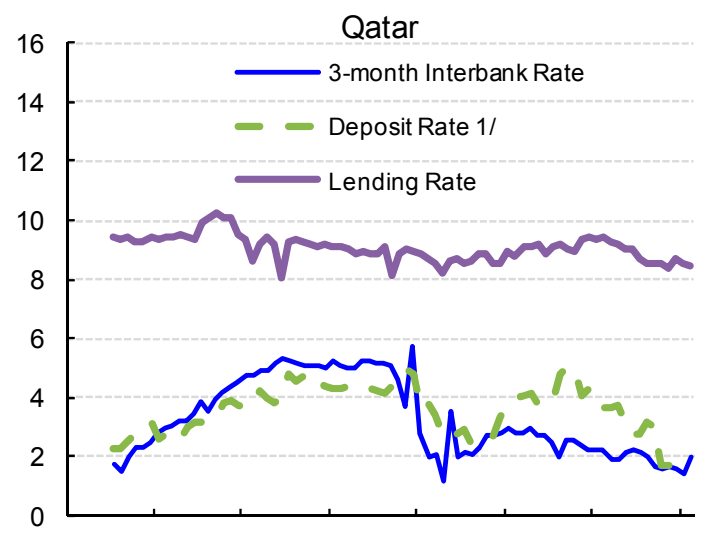

Jan-04 Jan-05 Jan-06 Jan-07 Jan-08 Jan-09 Jan-10 Jan-11 1/ One-year time deposit rate. 
For the empirical exercise, the weighted average deposit and lending rates are used. ${ }^{10}$ Panel estimates for the four GCC countries suggest that the interest rate pass-through was 0.30 and 0.50 for lending and deposit rates, respectively; i.e., a reduction of 100 basis points (bps) in the policy rate led to a reduction of almost $50 \mathrm{bps}$ in the banks' deposit rates and $30 \mathrm{bps}$ in their lending rates.

\section{GCC-wide panel long-term relationship (fixed-effect regression, estimation in levels)}

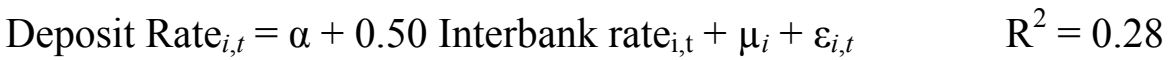

$$
\begin{aligned}
& \text { Lending Rate } \text { Rit, }=\alpha+0.30 \text { Interbank rate } \text { ret }_{i, t}+\mu_{i}+\varepsilon_{i, t} \quad \mathrm{R}^{2}=0.21
\end{aligned}
$$

Retail rates used in the estimates include rates on existing and new loans and deposits, so actual transmission to new deposit and loan rates might be somewhat higher. More importantly, the low pass-through reflects market frictions and regulations (see the discussion on country estimates below).

The pass-through estimates are subject to a number of limitations. In view of the relatively small sample size, the estimates are only indicative, as the error bands in the figures below show. Moreover, the sample includes a period before the global crisis that saw a significant increase in inflation, driven mainly by rents, and a period after the global crisis where policy rates were cut aggressively. Accordingly, the size and the speed of the pass-through could differ if, as some cross-country studies suggested, the pass-through when policy is tightened is different from the pass-through during monetary easing.

To assess possible changes in the pass-through over time, rolling regressions (with a moving sample of 36 months) are estimated. Rolling coefficients support the hypothesis of some improvement in pass-through to lending rates in the recent period. Taken together, the empirical evidence indicates that although pass-through is less than complete, there are signs of an increase in pass-through over time, reflecting policy efforts to impart greater flexibility to the interest rate structure in the economy.

\footnotetext{
${ }^{10}$ For Bahrain, the deposit rate is the average time deposit rate (three-month maturity) and the lending rate is the average lending rate (total, including overdraft approvals). For Kuwait and Oman, the rates are the weighted average deposit and lending rates across maturity. For Qatar, the deposit rate is the one-year time deposit rate, and the lending rate is for loans of maturity less than three years.
} 


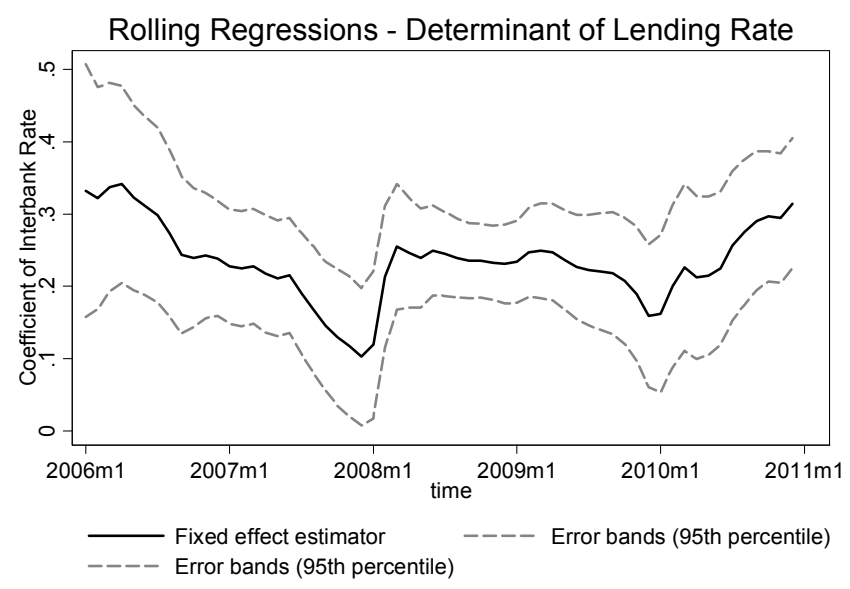

Note: Estimated $\beta$ of the regression: Lending Rate Ret $_{i, t}=\alpha+\beta$ Interbank Rate $_{i, t}+\mu_{\mathrm{i}}+\varepsilon_{i, t}$ Rolling window of 36 months

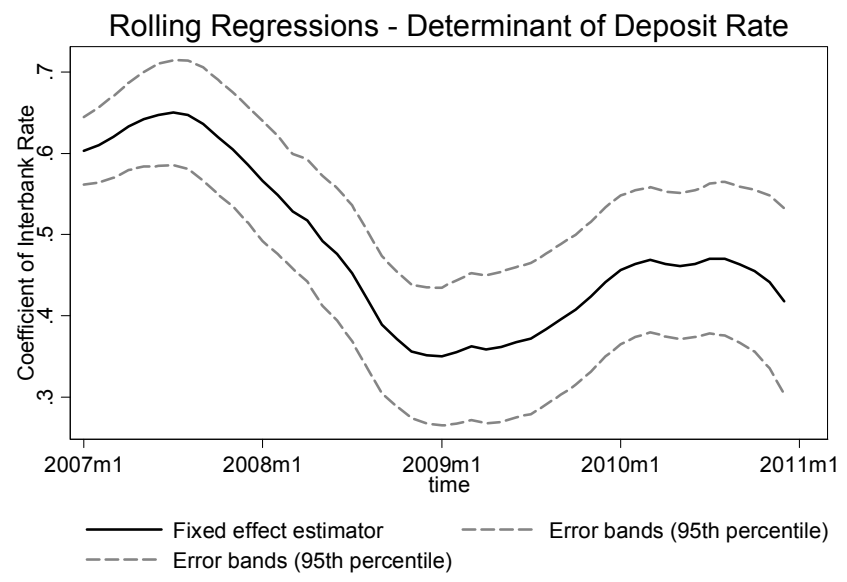

Note: Estimated $\beta$ of the regression: Deposit Rate $i, t=\alpha+\beta$ Interbank Rate $_{i, t}+\mu_{i}+\varepsilon_{i, t}$ Rolling window of 36 months

The above discussion seems to suggest that the pegged currency regime does not reduce monetary independence in the GCC, since the domestic interest rates do not fully reflect the U.S. interest rates. However, the mere presence of a differential between rates is not enough to inform on the extent of monetary policy independence. The pass-through could depend upon a number of factors such as: the structure of the financial system (e.g., the extent of the regulation of the financial system, ceilings on interest rates, and geographical and productline restrictions); the degree of competition between intermediaries; the usage of variablerate products (both deposits and loans) by the banking system; the existence of lottery systems for deposits; negative real interest rates for deposits over prolonged periods (as evidenced in Figure 3); the response of portfolio substitution to the policy rate; and the transparency of the monetary policy operations. A more detailed investigation of these factors requires a country-by-country study, to which we turn now. 
Figure 3. GCC Real Retail Interest Rates, 2004-11
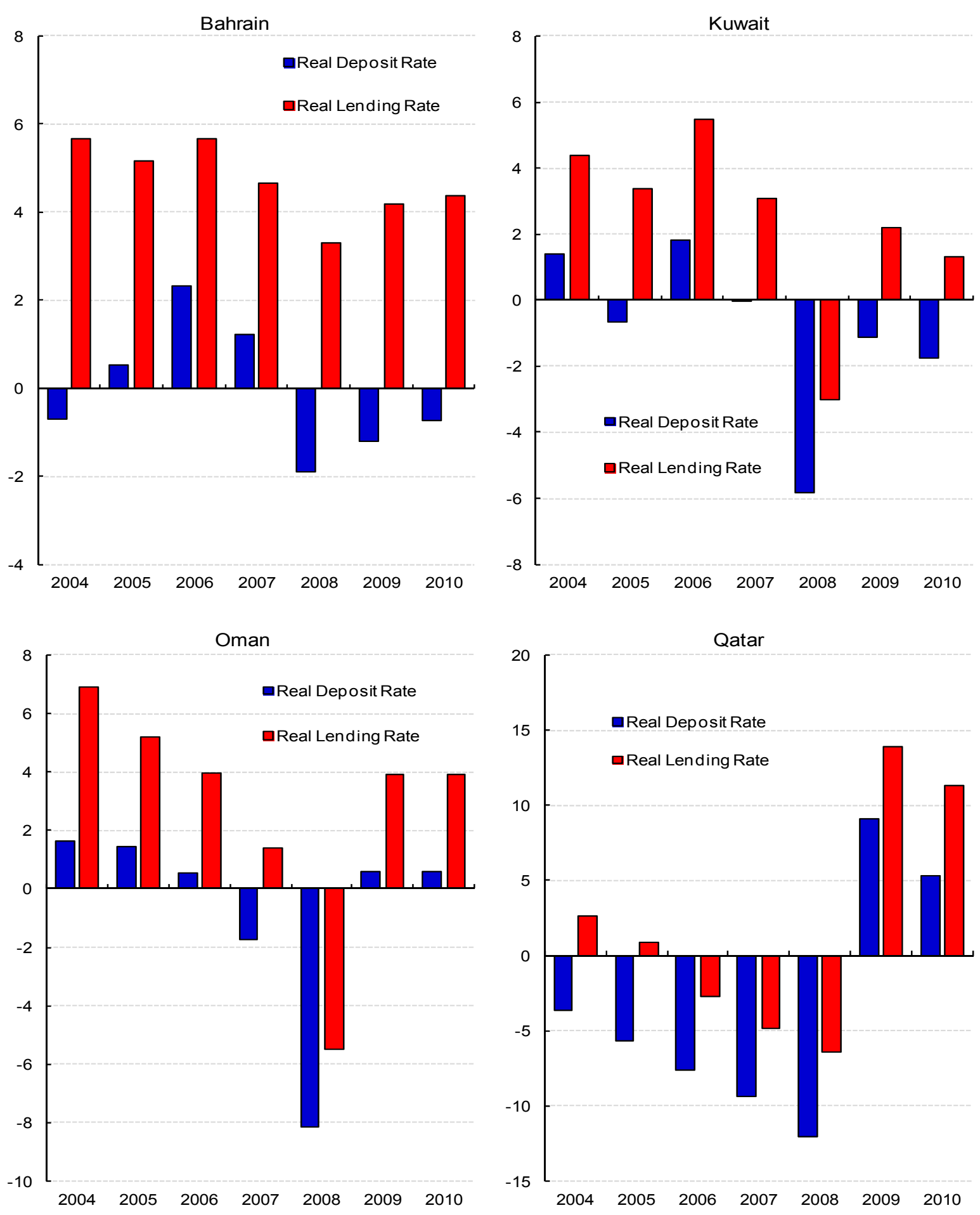

Sources: Haver Analytics; and country authorities. 


\section{Co-integration analysis and dynamic adjustment of lending and deposit rates to interbank rates}

This section analyses, country by country, the short-term dynamics and long-term transmission of interbank rates to bank rates using a simple co-integrated VAR. The cointegrated VAR is constructed for only two variables, the interbank rate $(I B)$ and the bank interest rate under study ( $R$ represents alternatively the deposit rate and the lending rate). More precisely, the following model is estimated on monthly data covering the period January 2004-December 2010:

$$
\left\{\begin{array}{l}
\Delta I B_{t}=\alpha^{1}+\sum_{1 \leq s \leq 11} \beta_{s}^{1} \Delta I B_{t-s}+\gamma_{s}^{1} \Delta R_{t-s}+\lambda^{1}(I B-R)_{t-12}+\varepsilon_{t}^{1} \\
\Delta R_{t}=\alpha^{2}+\sum_{1 \leq s \leq 11} \beta_{s}^{2} \Delta I B_{t-s}+\gamma_{s}^{2} \Delta R_{t-s}+\lambda^{2}(I B-R)_{t-12}+\varepsilon_{t}^{2}
\end{array}\right.
$$

The co integrated VAR is estimated with 12 lags. ${ }^{11}$ The long-term relationship is presented in Table 1, and the impulse response showing short-term adjustments is shown in Figure 4. The figure shows the orthogonalized impulse response functions, for the two co-integrated VAR models (interbank rate and lending rate; interbank rate and deposit rate) Shocks are identified thanks to Cholesky decomposition, where it is assumed that shocks originate first from interbank rates (i.e., the interbank rate is ordered first in the co-integrated VAR). The shock to the interbank rate has been normalized to a permanent one percentage point shock.

Deviations from full pass-through in the long-term relationship (i.e., coefficients lower than 1) are more likely due to regulations in the financial system (caps on interest rates, limits on portfolio shares based on products or geographical factors), lack of competition, and to portfolio substitution to the policy rate, which may matter in equilibrium. Slow pass-through in the short-term can also be caused by a lack of competition between intermediaries and by the limited use of variable-rate products.

Table 1 shows that the long-term relationship between interbank rates and bank lending and deposit rates is strongest for Bahrain and Kuwait. In Bahrain, an increase of 100 basis points in the interbank rate is associated, in the long run, with an increase of 63 basis points in the deposit rate, and an increase of 29 basis points in the lending rate. In Qatar, the relationship is weaker, though still significant for the deposit rate, while there is no relationship between

\footnotetext{
${ }^{11}$ The BIC and the Schwartz criteria suggested using a very long lag structure (more than 36 lags) but this is not compatible with the number of observations in the data set. Since these criteria tend to overestimate the number of lags needed, the model was restricted to the 12 lags that are typically needed with monthly data. For Kuwait, the lending rate-interbank rate co-integrated VAR was estimated with only 4 lags, and the deposit rateinterbank rate co-integrated VAR was estimated with 6 lags, because VARs with longer lags were unstable. The deposit rate-interbank rate VARs for Oman (6 lags) and for Bahrain (9 lags) were also estimated with a shorter lag structure for the same reason.
} 
rates in Oman. As expected, because competition for funds drives lending rates in the region, deposit rates are more clearly related to interbank rates compared to lending rates, which are strongly affected by the level (or rather lack of) competition.

Table 1. Co-integrating Vector

\begin{tabular}{lcc}
\hline Long-term sensitivity to interbank rate & Deposit Rate & Lending Rate \\
\hline Bahrain & 0.63 & 0.29 \\
Kuwait & 0.80 & 0.74 \\
Oman & -0.05 & 0.03 \\
Qatar & 0.20 & 0.01 \\
\hline
\end{tabular}

Source: Authors' calculations.

Note: Orthogonalized impulse response of deposit and lending rates to a shock in the interbank rate. The interbank rate is order first in the Cholesky decomposition, and the shocks in the interbank rate have been normalized to a permanent one percentage point shock. The error bands are the 90 percent Efron percentile error bands, computed using 500 bootstrap replications (see Efron and Tibshirani,1993).

Figure 4 also shows that lending rate adjustment is relatively slow in Bahrain, with rates adjusting fully after 20 months. In Kuwait, the adjustment of deposit rates and lending is also slow, with only half of the adjustment captured in the first six months after the shock. In Oman and in Qatar, shocks to the interbank rates do have an immediate effect on deposit and lending rates (albeit with a small sensitivity, of around 0.1 to 0.3 ) but most of the impact vanishes after 10 months.

In Oman, regulations in the banking sector are a likely cause of weak pass-through. Oman's regulations include a ceiling on personal lending of 40 percent of credit portfolio, and an interest rate cap. Limits to real estate lending, and both absolute and interest rate ceilings on personal loans assigned against salary, are also present in Qatar, where pass-through was also limited, especially in the long run. In Kuwait, the lending rates operate within a mandated ceiling benchmarked to the policy discount rate. Limits on consumer credit also exist in Bahrain.

Overall, the co-integrating VAR models show that the limits to the pass-through come essentially from distortions that are active over the long run, suggesting that regulations such as cap on interest rates or on portfolio shares are the main frictions limiting the impact of policy rates. However, the time-varying estimates have documented increases in passthrough over time, reflecting policy efforts to liberalize the banking sector. 
Figure 4. Dynamic Adjustment of Deposit and Lending Rates to Shocks in the Interbank Rates
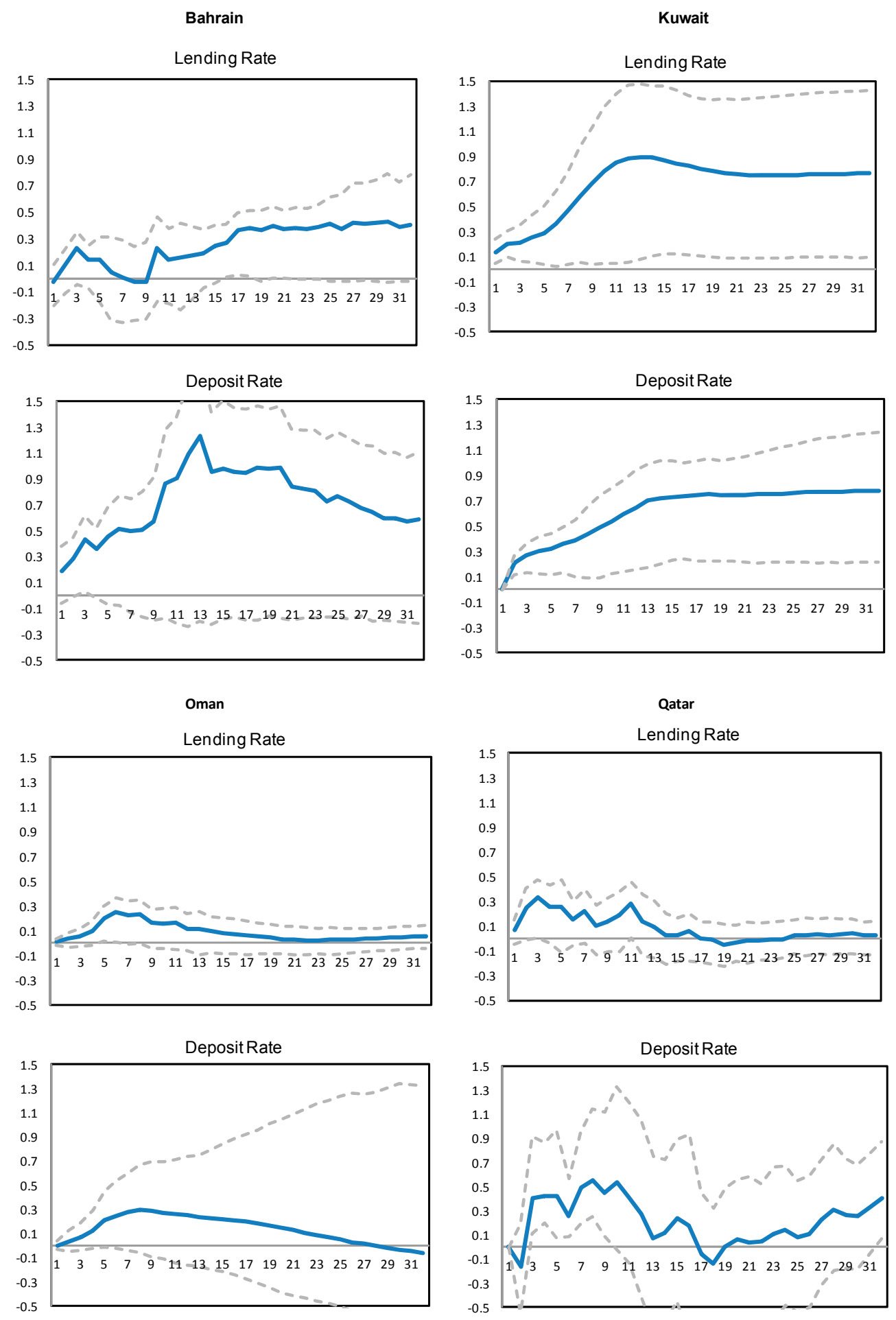
The forecast error variance decomposition of the co-integrated VAR model (Table 2) allows us to summarize the contribution of shocks to interbank rates to deposit and lending rates. We present the contribution at a horizon of one year. The contribution of shocks to interbank rates is high, except in Oman, where there is no long-term relationship. Shocks to interbank rates would contribute 30 to 57 percent of the variance of deposit and lending rates in the region. The countries in which the long-term relationship is the strongest (as shown in Table 2) are also the countries for which shocks to interbank rates matter the most, but interbank rates also contribute significantly to the variance of deposit and lending rates via short-term effects (as witnessed by the variance decomposition in Qatar).

Table 2. Forecast Error Variance Contribution

\begin{tabular}{lcc}
\hline $\begin{array}{l}\text { Forecast Error Variance Contribution of } \\
\text { interbank rate, 12 months ahead }\end{array}$ & Deposit Rate & Lending Rate \\
\hline Bahrain & 0.52 & 0.30 \\
Kuwait & 0.87 & 0.54 \\
Oman & 0.10 & 0.16 \\
Qatar & 0.38 & 0.28 \\
\hline
\end{tabular}

Source: Authors' calculations.

\section{Monetary Transmission in the GCC-A Panel VAR Approach}

The monetary transmission mechanism is the process by which monetary policy decisions influence economic outcomes such as output, employment, and inflation. Traditionally, four key channels of monetary policy transmission are identified: interest rate, credit aggregates, asset prices, and exchange rate channels. An expansionary monetary policy is expected to lead to a lowering of the cost of loanable funds, which in turn raises investment and consumption demand that eventually gets reflected in aggregate output and prices. Monetary policy also affects the supply of loanable funds, i.e., the credit channel. The credit channel makes a distinction between banks and nonbanks as sources of funds, and between internal and external finance, with bank lending as a sub-channel. A contractionary monetary policy that decreases bank reserves also curtails banks' lending capacity. Changes in interest rates could also induce movements in asset prices generating a wealth effect, which is commonly known as the asset price channel. High interest rates can induce an appreciation of domestic currency, leading to a reduction in net exports, and, hence, in aggregate demand and output; i.e., what is termed the exchange rate channel. The main channels of transmission in the GCC are likely to be the interest rate, credit, and asset price channels; under a fixed exchange rate regime the exchange rate channel is inactive.

We investigate the impact of monetary policy shocks in the region using a panel VAR on macroeconomic data for the six countries of the GCC. A VAR approach seems the most appropriate because it allows us to identify monetary policy shocks and to study their dynamic transmission through the economy. 
In a fixed exchange regime, monetary shocks have two origins. First, U.S. monetary policy affects local interest rates, credit, asset prices, and activity; it is therefore important to investigate the effect for U.S. policy. Second, given that GCC monetary authorities use many tools in the region (in addition to the policy rate), shocks to the money supply can also be interpreted as GCC monetary policy shocks.

A large empirical literature has investigated the impact of monetary policy using VAR models (e.g. Christiano, Eichenbaum, and Evans, 1999, for the United States; Sims, 1992, for several advanced economies). VAR models go beyond regressions because using simple regressions it is impossible to disentangle, for instance, the impact of an increase in interest rates on growth from the reverse causation stemming from the decision of a central bank to increase interest rates because growth is high. VAR models help 'explain the correlation' between interest rates and growth by making specific identifying assumptions: for instance, that monetary policy shocks have no immediate effect on growth. With this assumption, any contemporaneous correlation between policy rates and growth must be due to the response of policy to growth.

This strategy for identifying U.S. monetary policy shocks follows the literature on the U.S. economy (e.g., Christiano, Eichenbaum, and Evans, 1999; Hanson, 2004; see more details below) and we take a similar route. We extend the VAR model of the U.S. economy by including macroeconomic data on the GCC (non-oil growth and inflation), and we add the identifying assumption that GCC shocks do not contemporaneously influence U.S. variables. This approach has been used for instance by Miniane and Rogers (2007) to assess whether capital controls reduced the transmission of U.S. monetary policy shocks to other advanced and emerging economies.

Monetary VARs have been used on quarterly or even monthly data in advanced economies, but macroeconomic data in the GCC exist only at an annual frequency. The annual frequency of the data poses two serious challenges. The first one is that of sample size in VAR models that would include many variables (eight variables in total because we include variables for the United States and for the GCC). Macroeconomic data before 1980 are of little use given their uncertain quality and the structural break of the 1970s. As a result, the annual data set is too small to estimate a model country-by-country. This is why a panel VAR is our preferred model, although it is based on the restrictive assumption (especially given the analysis presented earlier in this paper) of homogeneity of coefficients in the different equations estimated.

The second problem is that the identification of U.S. monetary policy shocks is typically based on the assumption that the U.S. economy does not react to monetary shocks within the unit time period, which is why the preferred time unit in the literature has been a quarter, or even a month. We therefore investigate both VARs based on annual data and VARs based on quarterly data with annual GCC data interpolated into quarterly data. 


\section{A. Data}

An eight-variable panel VAR was estimated on non-oil real GDP (the 'GCC Y' variable), government expenditure (GCC G), CPI inflation (GCC P), and broad money (GCC M2) in the GCC, from 1980 to $2010 .{ }^{12}$ In addition, we used the Fed Funds Rate (FFR) as an indicator of imported monetary policy, and U.S. GDP (US Y), the U.S. Personal Consumption Deflator (US P)as well as the IMF agriculture commodity price index (COM P) to identify U.S. monetary shocks (see discussion below). The data come from IMF (2011) and BEA (2011). All variables but the Fed Funds Rate were expressed in logarithm and found to be I(1) in log-level but stationary in difference (including prices in the United States and in the GCC) according to the Levin-Lin-Chu panel unit root test.

\section{B. Annual Data Panel VAR}

The annual data VAR is estimated on log-levels (except for the Fed Funds Rate) using OLS, as is common in the literature (e.g. Christiano, Eichenbaum, and Evans, 1999). The VAR is estimated with three lags, because the size of the panel (162 observations) allows us to maintain enough degrees of freedom. The identification procedure is based on the Cholesky decomposition of the correlation matrix of the reduced-form residuals. This correlation matrix (Table 3) shows that shocks to world commodity prices are negatively correlated with shocks to economic activity in the United States. In addition, world commodity prices are positively correlated with U.S. inflation, U.S. policy rates, and government spending in the GCC. Shocks to growth and to the Fed Funds Rate are also strongly correlated, and there seems to be some contemporaneous correlation between growth in the United States and growth in the GCC.

In the Cholesky identification procedure, the commodity price index is ordered first, followed by U.S. GDP, U.S. prices and then the Fed Funds Rate. We also assume that the GCC variables are ordered after the U.S. variables, because it is unlikely that the macroeconomic situation of the GCC contemporaneously affects the United States. This ordering is also the one chosen by Miniane and Rogers (2007). The ordering of GCC variables is akin to that of U.S. variables in the monetary VAR literature: GDP is ordered first, followed by the CPI and the monetary aggregate M2. In addition, we added a variable capturing government spending (GCC G), and ordered it first among the GCC variables because government spending is planned ahead within a budget, and contemporaneously it is affected by oil revenues mostly, with little immediate feedback from growth (the tax base in very small in the GCC and the authorities did not use to run countercyclical fiscal policies in the region; see also Espinoza and Senhadji, 2011).

\footnotetext{
${ }^{12}$ Data for Oman and the UAE start in 1981; data for Qatar start in 1983.
} 


\section{Table 3. Correlation Matrix of Innovations}

\begin{tabular}{l|cccccccc} 
& COM P & US Y & US P & FFR & GCC G & GCCY & GCCP & GCC M2 \\
\hline COM P & 1.00 & & & & & & & \\
US Y & -0.27 & 1.00 & & & & & & \\
US P & 0.56 & -0.10 & 1.00 & & & & & \\
FFR & 0.15 & 0.39 & -0.12 & 1.00 & & & & \\
GCC G & 0.17 & -0.13 & 0.12 & 0.00 & 1.00 & & & \\
GCCY & 0.03 & 0.09 & 0.15 & -0.06 & 0.09 & 1.00 & & \\
GCCP & 0.01 & -0.02 & 0.02 & -0.09 & 0.04 & 0.02 & 1.00 & \\
GCC M2 & -0.07 & 0.07 & 0.08 & -0.01 & 0.01 & 0.18 & -0.15 & 1.00
\end{tabular}

The orthogonalized impulse response functions of the annual data VAR are shown in Figure 5. The error bands (excluding 10 percent of the simulations on each side, and therefore yielding statistical significance at the $90^{\text {th }}$ percentile) were constructed using 500 bootstrap replications, following the method of Runkle (1987). Shocks to the Fed Funds Rate of around 50 basis points reduce growth and prices in the United States in year 3 but have no effect on activity, prices, or broad money in the GCC. Permanent increases by 8 percent of broad money (M2, see the last column in Table 4), increased prices by 2 percent and non-oil GDP by slightly less than 1 percent.

However, we find that the VAR impulse responses suffer from a "Price Puzzle," the counterintuitive finding that increases in policy rates are followed by more inflation. A Price Puzzle is thought to indicate that the U.S. monetary policy has not been well identified (Zha, 1997; Sims, 1998). The inclusion of the IMF agriculture commodity price index as the first variable in the VAR is known to prevent the occurrence of the Price Puzzle in quarterly or monthly VAR, and the interpretation since Sims (1992) has been that commodity prices help forecast inflation and therefore are used by the Fed to take decisions on monetary policy. Therefore, forgetting this variable could lead to misestimating the systematic component (and therefore the shock component) of monetary policy (Zha,1997; Sims, 1998). ${ }^{13}$

However, the Price Puzzle was present in our baseline model with the IMF agricultural price index, and the result did not change when a different commodity price variable (the IMF global commodity price index) or a different U.S. price index (the U.S. CPI) was used; nor did it change when the model was estimated in growth rates as opposed to log-levels. These results confirm that it is difficult to identify a U.S. monetary policy shock using annual data. The (reduced-form) OLS estimates of the VAR (Table 4) may be in fact more informative than the orthogonalized impulse responses because to a large extent the U.S. variables (and the Fed Funds Rate) are exogenous in the GCC equations. Table 4 shows that the Fed Funds Rate is negatively related to non-oil GDP, CPI and M2 in the GCC, but the relationship is stronger with the third lag of the Fed Funds Rate.

\footnotetext{
${ }^{13}$ Hanson (2004) has argued that this interpretation is not supported by the data because the commodity prices that most reduce the Price Puzzle are not those that more accurately forecast future inflation.
} 
Table 4. OLS Estimates of the Annual VAR

\begin{tabular}{|c|c|c|c|c|c|c|c|c|}
\hline Equation & $\stackrel{(1)}{\text { COM_P }}$ & $\begin{array}{l}(2) \\
\text { US_Y }\end{array}$ & $\begin{array}{l}\text { (3) } \\
\text { US_P }\end{array}$ & $\begin{array}{c}(4) \\
\text { FFR }\end{array}$ & $\stackrel{(5)}{\text { GCC_G }}$ & $\stackrel{(6)}{G C C \_Y}$ & $\begin{array}{c}\text { (7) } \\
\text { GCC_P }\end{array}$ & $\stackrel{(8)}{\text { GCC_M2 }}$ \\
\hline$\left(\mathrm{COM} \_\mathrm{P}\right)_{-1}$ & $\begin{array}{c}0.350^{\star * *} \\
(0.106)\end{array}$ & $\begin{array}{c}-0.0731^{* * *} \\
(0.0185)\end{array}$ & $\begin{array}{l}-0.00344 \\
(0.00898)\end{array}$ & $\begin{array}{l}-2.026 \\
(1.593)\end{array}$ & $\begin{array}{l}0.0114 \\
(0.212)\end{array}$ & $\begin{array}{l}0.0638 \\
(0.121)\end{array}$ & $\begin{array}{l}-0.0335 \\
(0.0483)\end{array}$ & $\begin{array}{c}-0.155 \\
(0.117)\end{array}$ \\
\hline$\left(\mathrm{COM} \_\mathrm{P}\right)_{-2}$ & $\begin{array}{c}-0.530^{\star * *} \\
(0.0881)\end{array}$ & $\begin{array}{l}0.0315^{\star *} \\
(0.0154)\end{array}$ & $\begin{array}{c}-0.0118 \\
(0.00746)\end{array}$ & $\begin{array}{l}-0.509 \\
(1.380)\end{array}$ & $\begin{array}{l}-0.132 \\
(0.184)\end{array}$ & $\begin{array}{l}-0.155 \\
(0.105)\end{array}$ & $\begin{array}{l}-0.0179 \\
(0.0418)\end{array}$ & $\begin{array}{c}-0.308^{* * *} \\
(0.101)\end{array}$ \\
\hline$\left(\mathrm{COM} \_\mathrm{P}\right)_{-3}$ & $\begin{array}{c}0.122^{*} \\
(0.0689)\end{array}$ & $\begin{array}{c}0.0194 \\
(0.0120)\end{array}$ & $\begin{array}{c}0.0120^{\star \star} \\
(0.00583)\end{array}$ & $\begin{array}{c}1.196 \\
(1.053)\end{array}$ & $\begin{array}{c}0.130 \\
(0.140)\end{array}$ & $\begin{array}{c}0.122 \\
(0.0800)\end{array}$ & $\begin{array}{l}-0.0267 \\
(0.0319)\end{array}$ & $\begin{array}{r}-0.00277 \\
(0.0774)\end{array}$ \\
\hline$\left(U S \_Y\right)_{-1}$ & $\begin{array}{c}-3.487^{\star \star \star} \\
(0.678)\end{array}$ & $\begin{array}{c}1.059^{\star \star \star} \\
(0.118)\end{array}$ & $\begin{array}{l}-0.0719 \\
(0.0573)\end{array}$ & $\begin{array}{c}28.65^{\star \star \star} \\
(9.158)\end{array}$ & $\begin{array}{c}0.399 \\
(1.220)\end{array}$ & $\begin{array}{c}0.809 \\
(0.697)\end{array}$ & $\begin{array}{l}-0.0736 \\
(0.278)\end{array}$ & $\begin{array}{l}1.321^{*} \\
(0.673)\end{array}$ \\
\hline$\left(U S \_Y\right)_{-2}$ & $\begin{array}{c}-2.128^{\star \star *} \\
(0.657)\end{array}$ & $\begin{array}{c}-0.727^{\star \star *} \\
(0.115)\end{array}$ & $\begin{array}{l}-0.144^{\star \star} \\
(0.0556)\end{array}$ & $\begin{array}{c}-76.37^{* * *} \\
(10.11)\end{array}$ & $\begin{array}{c}-2.122 \\
(1.346)\end{array}$ & $\begin{array}{c}-2.602^{\star * \star} \\
(0.769)\end{array}$ & $\begin{array}{l}-0.471 \\
(0.306)\end{array}$ & $\begin{array}{c}-3.631^{\star * *} \\
(0.743)\end{array}$ \\
\hline$\left(U S \_Y\right)_{-3}$ & $\begin{array}{c}4.220^{\star \star \star} \\
(0.500)\end{array}$ & $\begin{array}{l}0.715^{\star \star \star} \\
(0.0872)\end{array}$ & $\begin{array}{l}0.316^{\star \star *} \\
(0.0423)\end{array}$ & $\begin{array}{c}53.12^{\star \star \star} \\
(8.113)\end{array}$ & $\begin{array}{l}2.163^{\star *} \\
(1.081)\end{array}$ & $\begin{array}{c}1.937^{\star \star \star} \\
(0.617)\end{array}$ & $\begin{array}{l}0.467^{*} \\
(0.246)\end{array}$ & $\begin{array}{c}2.082^{\star \star \star} \\
(0.596)\end{array}$ \\
\hline$(\text { US_P })_{-1}$ & $\begin{array}{l}-0.499 \\
(1.169)\end{array}$ & $\begin{array}{c}-1.521^{\star \star *} \\
(0.204)\end{array}$ & $\begin{array}{l}1.169^{\star \star *} \\
(0.0989)\end{array}$ & $\begin{array}{c}-38.51^{\star *} \\
(18.72)\end{array}$ & $\begin{array}{c}2.129 \\
(2.494)\end{array}$ & $\begin{array}{c}0.399 \\
(1.424)\end{array}$ & $\begin{array}{l}-0.375 \\
(0.567)\end{array}$ & $\begin{array}{c}0.925 \\
(1.376)\end{array}$ \\
\hline$\left(U S \_P\right)_{-2}$ & $\begin{array}{l}-2.171 \\
(2.044)\end{array}$ & $\begin{array}{c}1.392^{\star \star \star} \\
(0.357)\end{array}$ & $\begin{array}{c}-0.422^{\star \star} \\
(0.173)\end{array}$ & $\begin{array}{c}18.17 \\
(33.21)\end{array}$ & $\begin{array}{l}-2.612 \\
(4.423)\end{array}$ & $\begin{array}{l}0.0724 \\
(2.525)\end{array}$ & $\begin{array}{c}0.802 \\
(1.006)\end{array}$ & $\begin{array}{c}1.774 \\
(2.440)\end{array}$ \\
\hline$(\text { US_P })_{-3}$ & $\begin{array}{c}4.131^{\star * *} \\
(1.283)\end{array}$ & $\begin{array}{c}-0.0509 \\
(0.224)\end{array}$ & $\begin{array}{l}0.0799 \\
(0.109)\end{array}$ & $\begin{array}{c}2.875 \\
(21.16)\end{array}$ & $\begin{array}{c}0.00965 \\
(2.818)\end{array}$ & $\begin{array}{l}-0.813 \\
(1.609)\end{array}$ & $\begin{array}{l}-0.307 \\
(0.641)\end{array}$ & $\begin{array}{l}-1.914 \\
(1.555)\end{array}$ \\
\hline$(F F R)_{-1}$ & $\begin{array}{l}0.0288^{\star \star *} \\
(0.00836)\end{array}$ & $\begin{array}{l}0.00365^{\star *} \\
(0.00146)\end{array}$ & $\begin{array}{l}0.00316^{\star \star *} \\
(0.000707)\end{array}$ & $\begin{array}{c}0.794^{\star \star *} \\
(0.116)\end{array}$ & $\begin{array}{l}0.00379 \\
(0.0154)\end{array}$ & $\begin{array}{l}-0.00316 \\
(0.00879)\end{array}$ & $\begin{array}{l}0.00681^{*} \\
(0.00350)\end{array}$ & $\begin{array}{c}0.0109 \\
(0.00849)\end{array}$ \\
\hline$(F F R)_{-2}$ & $\begin{array}{l}-0.00281 \\
(0.00797)\end{array}$ & $\begin{array}{l}-0.00240^{*} \\
(0.00139)\end{array}$ & $\begin{array}{c}-0.00233^{* * *} \\
(0.000674)\end{array}$ & $\begin{array}{l}-0.171 \\
(0.111)\end{array}$ & $\begin{array}{r}-0.00329 \\
(0.0148)\end{array}$ & $\begin{array}{c}0.00646 \\
(0.00842)\end{array}$ & $\begin{array}{l}-0.00213 \\
(0.00336)\end{array}$ & $\begin{array}{c}0.0131 \\
(0.00814)\end{array}$ \\
\hline$(\mathrm{FFR})_{-3}$ & $\begin{array}{c}-0.0527^{\star * *} \\
(0.00551)\end{array}$ & $\begin{array}{c}-0.00389^{* * *} \\
(0.000962)\end{array}$ & $\begin{array}{c}-0.00194^{* * *} \\
(0.000466)\end{array}$ & $\begin{array}{c}-0.504^{* * *} \\
(0.0876)\end{array}$ & $\begin{array}{c}-0.0100 \\
(0.0117)\end{array}$ & $\begin{array}{l}-0.0162^{* *} \\
(0.00666)\end{array}$ & $\begin{array}{c}-0.00732^{* * *} \\
(0.00266)\end{array}$ & $\begin{array}{c}-0.0280^{\star * *} \\
(0.00644)\end{array}$ \\
\hline$\left(G C C \_G\right)_{-1}$ & $\begin{array}{l}-0.0339 \\
(0.0395)\end{array}$ & $\begin{array}{c}0.0109 \\
(0.00689)\end{array}$ & $\begin{array}{r}-0.000676 \\
(0.00334)\end{array}$ & $\begin{array}{l}-0.801 \\
(0.647)\end{array}$ & $\begin{array}{l}0.898^{* * *} \\
(0.0862)\end{array}$ & $\begin{array}{l}0.186^{* * *} \\
(0.0492)\end{array}$ & $\begin{array}{c}0.0266 \\
(0.0196)\end{array}$ & $\begin{array}{c}0.0582 \\
(0.0476)\end{array}$ \\
\hline$\left(G C C \_G\right)_{-2}$ & $\begin{array}{c}0.0845 \\
(0.0532)\end{array}$ & $\begin{array}{l}-0.0240^{\star *} \\
(0.00928)\end{array}$ & $\begin{array}{c}0.00178 \\
(0.00450)\end{array}$ & $\begin{array}{l}-0.0118 \\
(0.873)\end{array}$ & $\begin{array}{c}-0.146 \\
(0.116)\end{array}$ & $\begin{array}{l}-0.0763 \\
(0.0664)\end{array}$ & $\begin{array}{l}-0.0295 \\
(0.0265)\end{array}$ & $\begin{array}{c}-0.106^{*} \\
(0.0641)\end{array}$ \\
\hline$\left(G C C \_G\right)_{-3}$ & $\begin{array}{l}-0.0609 \\
(0.0411)\end{array}$ & $\begin{array}{c}0.0162^{* *} \\
(0.00717)\end{array}$ & $\begin{array}{l}-0.00153 \\
(0.00348)\end{array}$ & $\begin{array}{c}0.866 \\
(0.673)\end{array}$ & $\begin{array}{c}0.200^{* *} \\
(0.0896)\end{array}$ & $\begin{array}{l}-0.119^{* *} \\
(0.0511)\end{array}$ & $\begin{array}{l}0.00703 \\
(0.0204)\end{array}$ & $\begin{array}{c}0.0898^{*} \\
(0.0494)\end{array}$ \\
\hline$\left(\mathrm{GCC} \_\mathrm{Y}\right)_{-1}$ & $\begin{array}{c}-0.103 \\
(0.0634)\end{array}$ & $\begin{array}{c}0.0409^{* * *} \\
(0.0111)\end{array}$ & $\begin{array}{l}0.000226 \\
(0.00537)\end{array}$ & $\begin{array}{c}1.756^{*} \\
(1.030)\end{array}$ & $\begin{array}{l}0.260^{*} \\
(0.137)\end{array}$ & $\begin{array}{l}0.715^{\star * *} \\
(0.0783)\end{array}$ & $\begin{array}{l}0.00379 \\
(0.0312)\end{array}$ & $\begin{array}{c}0.119 \\
(0.0757)\end{array}$ \\
\hline$\left(G C C \_Y\right)_{-2}$ & $\begin{array}{l}-0.0289 \\
(0.0756)\end{array}$ & $\begin{array}{c}-0.0428^{\star \star \star} \\
(0.0132)\end{array}$ & $\begin{array}{l}-0.00415 \\
(0.00640)\end{array}$ & $\begin{array}{l}-1.512 \\
(1.245)\end{array}$ & $\begin{array}{l}-0.268 \\
(0.166)\end{array}$ & $\begin{array}{l}0.302^{\star * *} \\
(0.0947)\end{array}$ & $\begin{array}{l}-0.0211 \\
(0.0377)\end{array}$ & $\begin{array}{c}-0.260^{* * *} \\
(0.0915)\end{array}$ \\
\hline$\left(\mathrm{GCC} \_\mathrm{Y}\right)_{-3}$ & $\begin{array}{l}0.132^{\star *} \\
(0.0552)\end{array}$ & $\begin{array}{c}0.00164 \\
(0.00963)\end{array}$ & $\begin{array}{c}0.00393 \\
(0.00467)\end{array}$ & $\begin{array}{l}-0.220 \\
(0.903)\end{array}$ & $\begin{array}{l}0.0150 \\
(0.120)\end{array}$ & $\begin{array}{c}-0.0189 \\
(0.0687)\end{array}$ & $\begin{array}{c}0.0144 \\
(0.0274)\end{array}$ & $\begin{array}{c}0.134^{\star *} \\
(0.0663)\end{array}$ \\
\hline$\left(G C C \_P\right)_{-1}$ & $\begin{array}{c}0.209 \\
(0.194)\end{array}$ & $\begin{array}{c}-0.0630^{*} \\
(0.0339)\end{array}$ & $\begin{array}{c}0.0196 \\
(0.0164)\end{array}$ & $\begin{array}{c}3.111 \\
(2.957)\end{array}$ & $\begin{array}{c}0.398 \\
(0.394)\end{array}$ & $\begin{array}{l}-0.237 \\
(0.225)\end{array}$ & $\begin{array}{l}1.521^{* * *} \\
(0.0896)\end{array}$ & $\begin{array}{c}0.167 \\
(0.217)\end{array}$ \\
\hline$\left(G C C \_P\right)_{-2}$ & $\begin{array}{l}-0.536 \\
(0.348)\end{array}$ & $\begin{array}{l}0.161^{* * *} \\
(0.0607)\end{array}$ & $\begin{array}{l}-0.0370 \\
(0.0294)\end{array}$ & $\begin{array}{c}2.245 \\
(5.191)\end{array}$ & $\begin{array}{l}-0.356 \\
(0.691)\end{array}$ & $\begin{array}{l}-0.255 \\
(0.395)\end{array}$ & $\begin{array}{c}-0.728^{\star * *} \\
(0.157)\end{array}$ & $\begin{array}{l}-0.259 \\
(0.382)\end{array}$ \\
\hline$\left(G C C \_P\right)_{-3}$ & $\begin{array}{l}0.366^{*} \\
(0.218)\end{array}$ & $\begin{array}{c}-0.107^{\star * *} \\
(0.0381)\end{array}$ & $\begin{array}{c}0.0185 \\
(0.0185)\end{array}$ & $\begin{array}{l}-5.372 \\
(3.367)\end{array}$ & $\begin{array}{l}0.0537 \\
(0.449)\end{array}$ & $\begin{array}{l}0.642^{\star *} \\
(0.256)\end{array}$ & $\begin{array}{l}0.183^{*} \\
(0.102)\end{array}$ & $\begin{array}{c}0.161 \\
(0.247)\end{array}$ \\
\hline$(\text { GCC_M2) })_{-1}$ & $\begin{array}{l}-0.0356 \\
(0.0720)\end{array}$ & $\begin{array}{c}0.0170 \\
(0.0126)\end{array}$ & $\begin{array}{c}0.00162 \\
(0.00609)\end{array}$ & $\begin{array}{l}-0.657 \\
(1.159)\end{array}$ & $\begin{array}{l}0.0434 \\
(0.154)\end{array}$ & $\begin{array}{c}0.125 \\
(0.0881)\end{array}$ & $\begin{array}{c}0.0172 \\
(0.0351)\end{array}$ & $\begin{array}{l}0.901^{* * *} \\
(0.0852)\end{array}$ \\
\hline$(\text { GCC_M2) })_{-2}$ & $\begin{array}{l}-0.0200 \\
(0.0934)\end{array}$ & $\begin{array}{c}-0.0415^{\star *} \\
(0.0163)\end{array}$ & $\begin{array}{l}-0.0166^{* *} \\
(0.00790)\end{array}$ & $\begin{array}{c}0.357 \\
(1.516)\end{array}$ & $\begin{array}{l}0.0407 \\
(0.202)\end{array}$ & $\begin{array}{l}-0.113 \\
(0.115)\end{array}$ & $\begin{array}{c}-0.000106 \\
(0.0460)\end{array}$ & $\begin{array}{l}0.0418 \\
(0.111)\end{array}$ \\
\hline$\left(G C C \_M 2\right)_{-3}$ & $\begin{array}{c}0.0642 \\
(0.0678)\end{array}$ & $\begin{array}{l}0.0220^{*} \\
(0.0118)\end{array}$ & $\begin{array}{l}0.0154^{\star \star \star} \\
(0.00573)\end{array}$ & $\begin{array}{c}0.206 \\
(1.112)\end{array}$ & $\begin{array}{c}-0.0514 \\
(0.148)\end{array}$ & $\begin{array}{r}-0.00696 \\
(0.0846)\end{array}$ & $\begin{array}{l}-0.0151 \\
(0.0337)\end{array}$ & $\begin{array}{c}0.0243 \\
(0.0817)\end{array}$ \\
\hline Constant & $\begin{array}{c}11.57^{* * *} \\
(1.318)\end{array}$ & $\begin{array}{c}0.601^{\star \star *} \\
(0.230)\end{array}$ & $\begin{array}{l}-0.107 \\
(0.111)\end{array}$ & $\begin{array}{l}39.70^{*} \\
(21.08)\end{array}$ & $\begin{array}{c}-2.345 \\
(2.808)\end{array}$ & $\begin{array}{c}-0.509 \\
(1.603)\end{array}$ & $\begin{array}{c}0.710 \\
(0.639)\end{array}$ & $\begin{array}{c}0.573 \\
(1.549)\end{array}$ \\
\hline Observations & 162 & 162 & 162 & 168 & 168 & 168 & 168 & 168 \\
\hline
\end{tabular}

Standard errors in parentheses.

${ }^{* * *} p<0.01,{ }^{* *} p<0.05,{ }^{*} p<0.1$

(C)International Monetary Fund. Not for Redistribution 


\section{Quarterly Data Panel VAR}

We turn now to the results of the quarterly data panel VAR. The annual data for the GCC were interpolated using cubic spline interpolation ${ }^{14}$ and the VAR model was estimated with four lags (as suggested by the Aikake and Schwarz information criteria - see also the robustness exercises below). The orthogonalized impulse response functions (IRFs) for the baseline VAR (with the same ordering as the annual data VAR) are shown in Figure 6. Although the VAR was estimated using the interpolated quarterly data, the IRFs for the GCC variables have been converted into annual IRFs because their quarterly dynamics is due to their own interpolations.

The quarterly U.S.-GCC VAR model is free of the Price Puzzle issue, and the impulse responses closely resemble those obtained for the United States in the literature (Hanson, 2004). This result increases our confidence that the U.S. monetary shocks are better identified in the quarterly VAR. An increase in the U.S. policy rate by 100 basis points reduces after 10 quarters U.S. activity and U.S. prices by about 0.1 percent. The reduction in U.S. activity is marginally insignificant at the $90^{\text {th }}$ percent level. The monetary policy shock has also a strong effect on world commodity prices (a reduction by 2 percent), and probably as a result of this, on GCC prices which are reduced by 0.8 percent 10 quarters after the shock (this result is statistically significant at the $90^{\text {th }}$ percent level). Non-oil GDP in the GCC is also reduced by around 0.1 percent and M2 by 0.6 percent, but these impulse response functions are not significantly different from 0 . Shocks to M2 increase prices in the GCC with an elasticity of around 0.3 , but the effect on economic activity is insignificant. These results suggest that monetary policy as run by GCC central banks, with a focus on monetary aggregates given the limits of the peg, is important for price stability but has a limited effect on economic activity.

The VAR also provides some interesting results regarding the impact of the other variables, although this is not the primary objective of the analysis. Shocks to world commodity prices boost government spending, certainly because there is a strong relationship between oil revenues and government spending in the region. In turn, shocks to government spending increase non-oil GDP, with an elasticity of around 0.1 after 10 quarters. Shocks to U.S. GDP have positive spillovers on GCC non-oil GDP, with an elasticity of 0.9 after 10 quarters. Finally, according to the forecast error variance decomposition, the main drivers of non-oil GDP are commodity prices, government spending, and U.S. growth. As is often found in monetary VARs, monetary policy shocks contribute relatively little to the variance of economic activity.

\footnotetext{
${ }^{14}$ Data for broad money, which are available at the quarterly frequency, were also interpolated from annual data to maintain a consistent method for GCC data.
} 


\section{Robustness}

We present the responses of a shock to the Fed Funds Rate for different modifications to the baseline VAR in Figures 7 and 8. In Figure 7, the IRFs of VARs estimated dropping one country at a time are drawn, to indicate the importance of the homogeneity assumption of the panel. The figure shows that the IRF is robust to the exclusion of data from the United Arab Emirates, Qatar, Bahrain, or Oman (VAR 2 to VAR 5). Excluding data from Saudi Arabia or Kuwait (VAR 6 and VAR 7) results, however, in a different, and counterintuitive, IRF for GCC prices. Saudi Arabia and Kuwait are the largest economies of the GCC, and the countries with better data quality. We therefore think the specifications that include these two countries in the sample (VAR1 to VAR5) are more representative of the GCC economy.

The second set of robustness exercises consists in changing the number of lags in the model, the time period for the estimation, and the ordering of the variables with particular reference to the Fed Funds Rate (Figure 8). The IRF to a shock in the Fed Funds Rate is almost unchanged when adding one lag to the model (VAR 9); however, a Price Puzzle emerges again when the model includes eight lags (VAR 10), though after three years the impact of monetary tightening on prices in the U.S. and in the GCC is again negative.

The identification of a U.S. monetary policy shock also seems also less robust when the data are restricted to the second part of our sample (1995-2010, VAR 12). In that period, there is a remaining, although minor, Price Puzzle, as the U.S. monetary policy shock is followed by a small increase in U.S. prices. ${ }^{15}$ More significantly, over that period, the U.S. monetary policy shock is counter-intuitively followed by an increase in U.S. growth, world commodity prices, and probably, as a result, GCC growth, for the first two years after the shock. The VAR estimate over the earlier period (1980-94, VAR 11) is more in line with theoretical priors. World commodity prices, U.S. inflation, U.S. growth, GCC growth, GCC inflation, and broad money all decrease after the U.S. monetary policy shock, roughly in line with what was found over the entire sample.

Finally, the estimated impact of U.S. monetary policy shocks on GCC prices did not seem to depend much on the specific position of the Fed Funds Rate (see VAR 13 and VAR 14), although the different ordering did generate an unappealing impact of U.S. monetary policy on global price, U.S. growth, and, as a result, on GCC growth.

\footnotetext{
${ }^{15}$ Hanson (2004) noted that the Price Puzzle was also stronger over the period 1959-79.
} 


\section{Summary AND Policy IMPlications}

Our analysis indicates that the GCC three-month interbank rates closely mirrored the U.S. rates only in Bahrain and Saudi Arabia. In Kuwait, Qatar, and the United Arab Emirates, there are deviations in different degrees, particularly after the global crisis. The pass-through of changes in the local interbank rates to local deposit and lending rates in the four countries analyzed-Bahrain, Kuwait, Oman, and Qatar-is less than complete. A co-integration analysis shows that the long-term relationship between interbank rates and bank lending and deposit rates is strongest for Bahrain and Kuwait. Our panel VAR model suggests that U.S. monetary policy has a strong and statistically significant impact on broad money, non-oil activity, and inflation in the GCC region. An increase of 100 basis points in the Fed Funds Rate decreases broad money growth by 0.6 percentage point and non-oil activity by 0.1 percent 10 quarters after the shock. Global commodity prices are also reduced by 2 percent, which contributes to lower inflation in the GCC (-0.8 percent).

The low pass-through of interest rates is not surprising, given the shallowness of money markets in the GCC countries. Policy signals will transmit quickly and more efficiently onto market rates if the financial system is well diversified in institutions and instruments. A thin market would typically display a high degree of volatility in interest rates, making it difficult for market participants to disentangle noise from policy signals, and this may reduce the pass-through. The existence of arbitrary limits on lending and interest rate ceilings would limit the transmission of interest rate movements. Continued efforts to develop domestic financial markets should be the key focus of increasing interest rate pass-through and strengthening monetary policy transmission. 


\section{Figure 5. Annual Data Panel VAR}

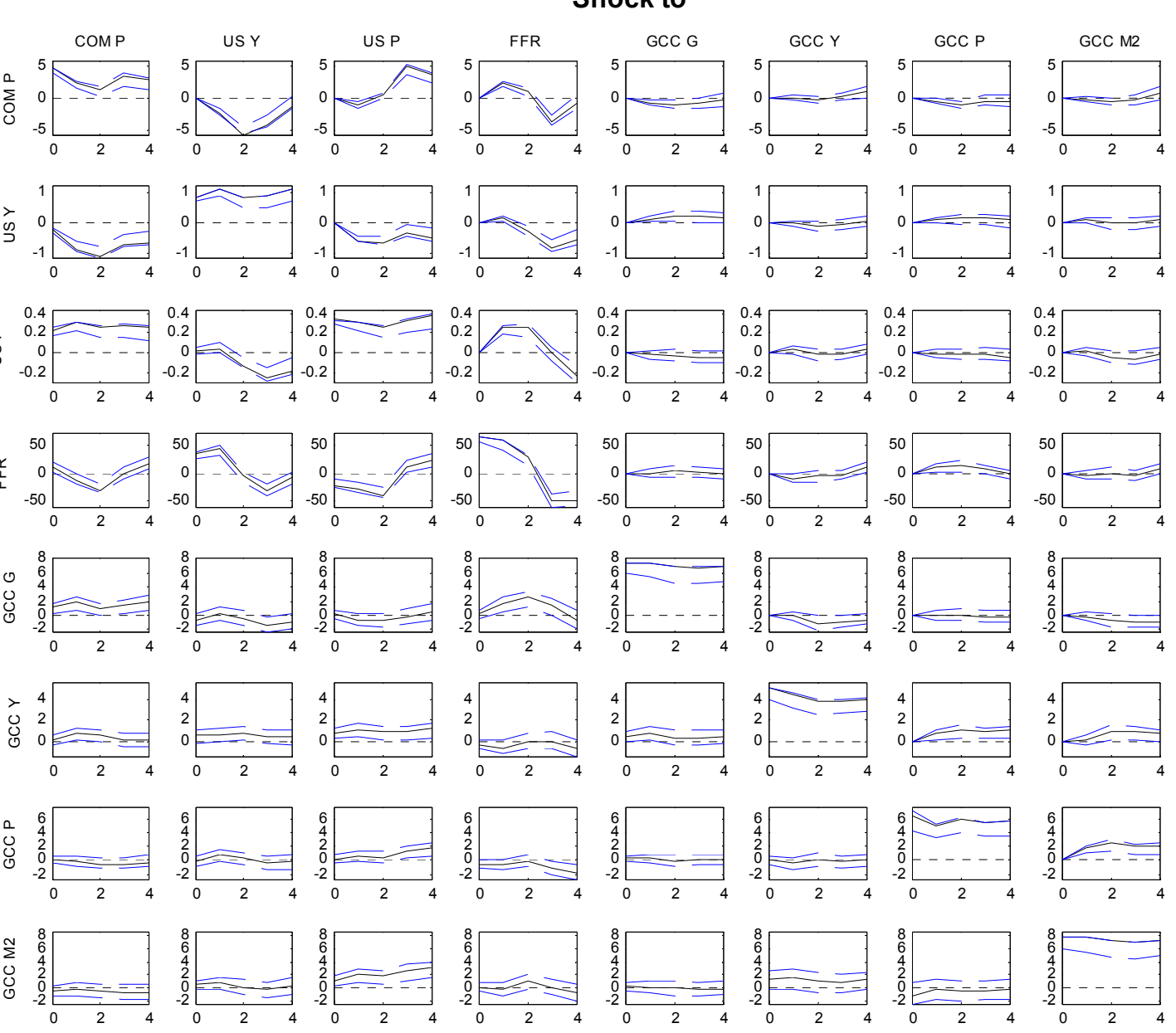




\section{Figure 6. Quarterly Data Panel VAR}

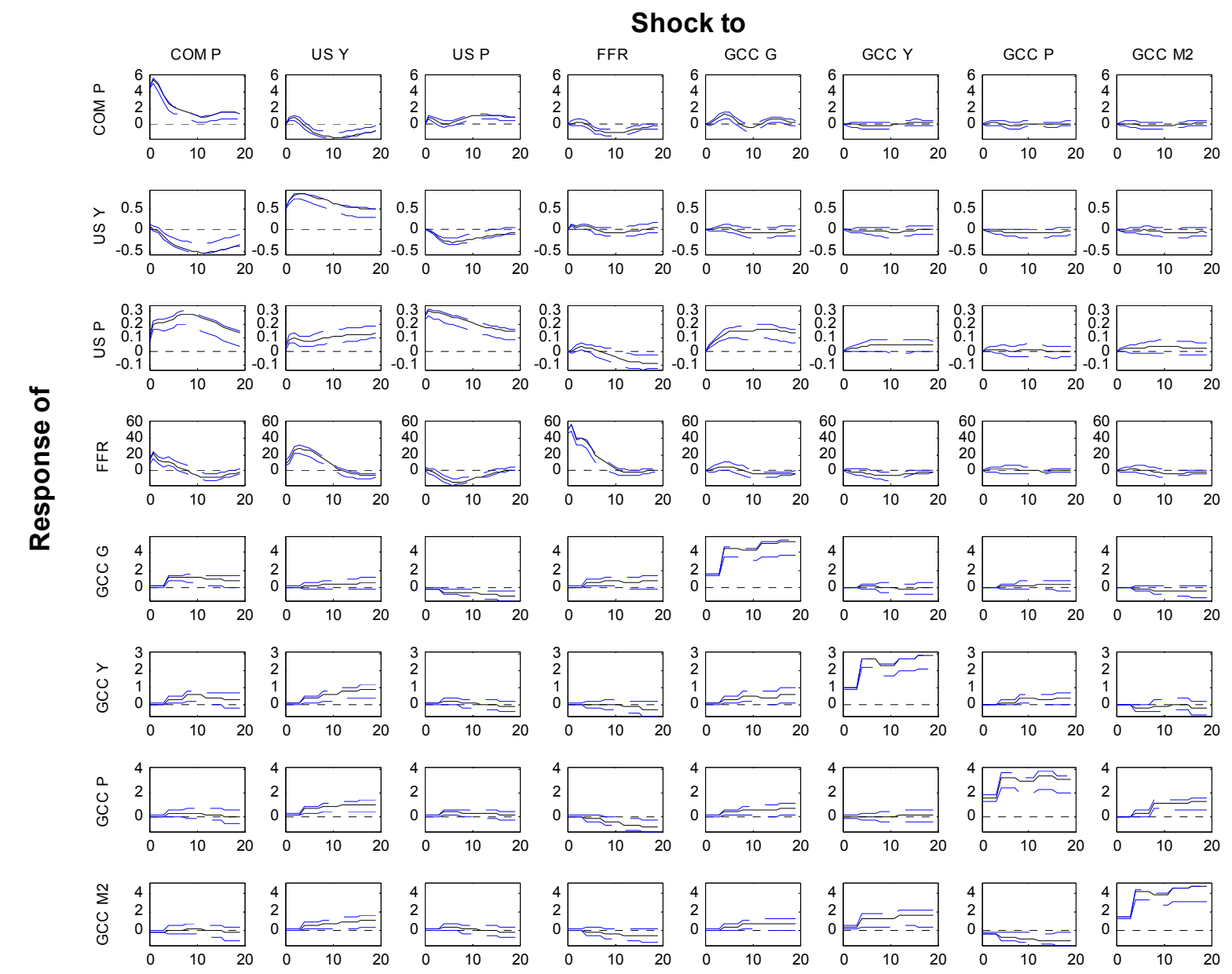

CInternational Monetary Fund. Not for Redistribution 


\section{Figure 7. Robustness to Country Composition}

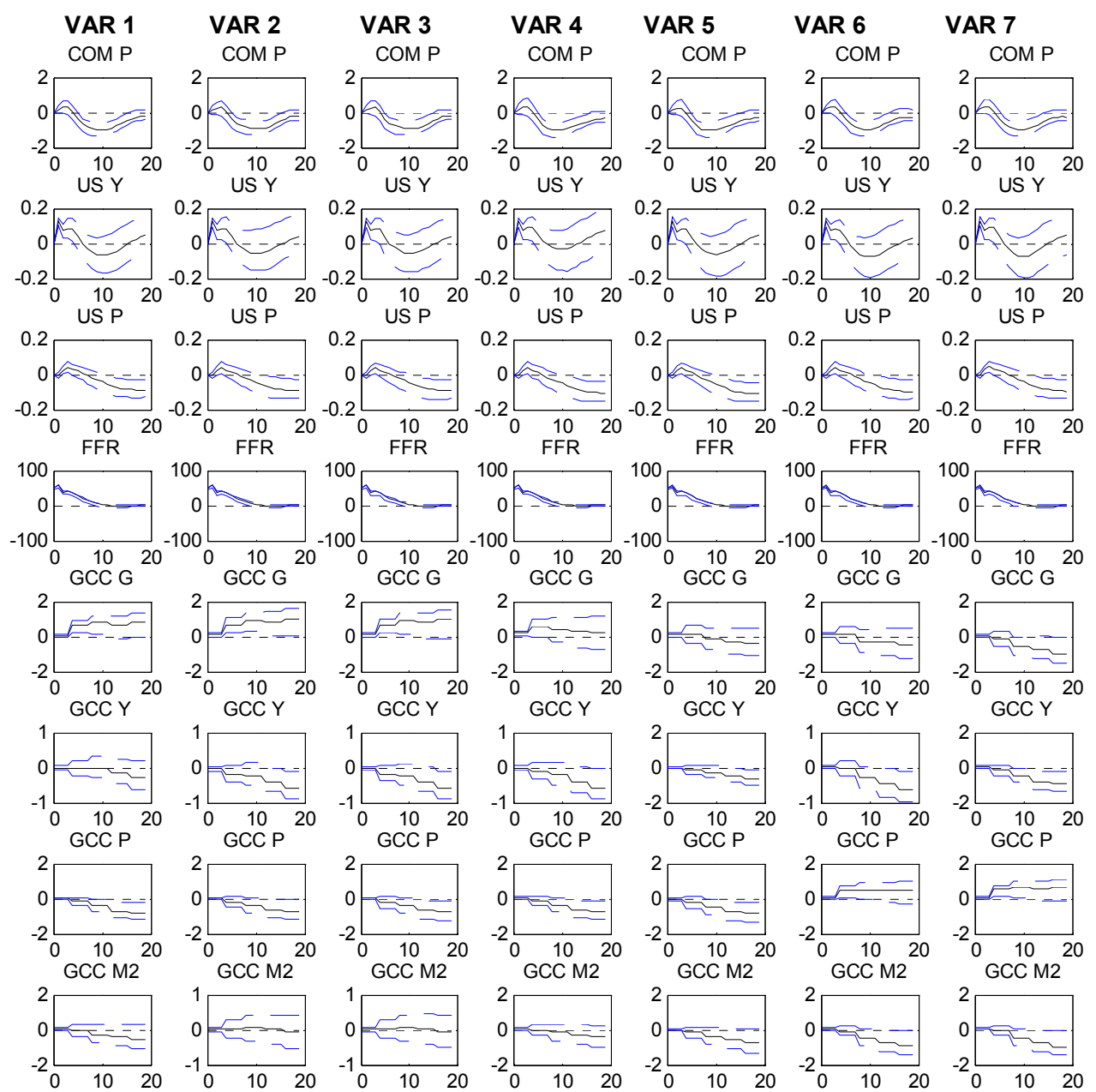

VAR 1: all countries; VAR 2: excluding the UAE; VAR 3: excluding Qatar; VAR 4: excluding Bahrain; VAR 5: excluding Oman; VAR 6: excluding Kuwait; VAR 7: excluding Saudi Arabia 
Figure 8. Robustness to VAR Specification Composition

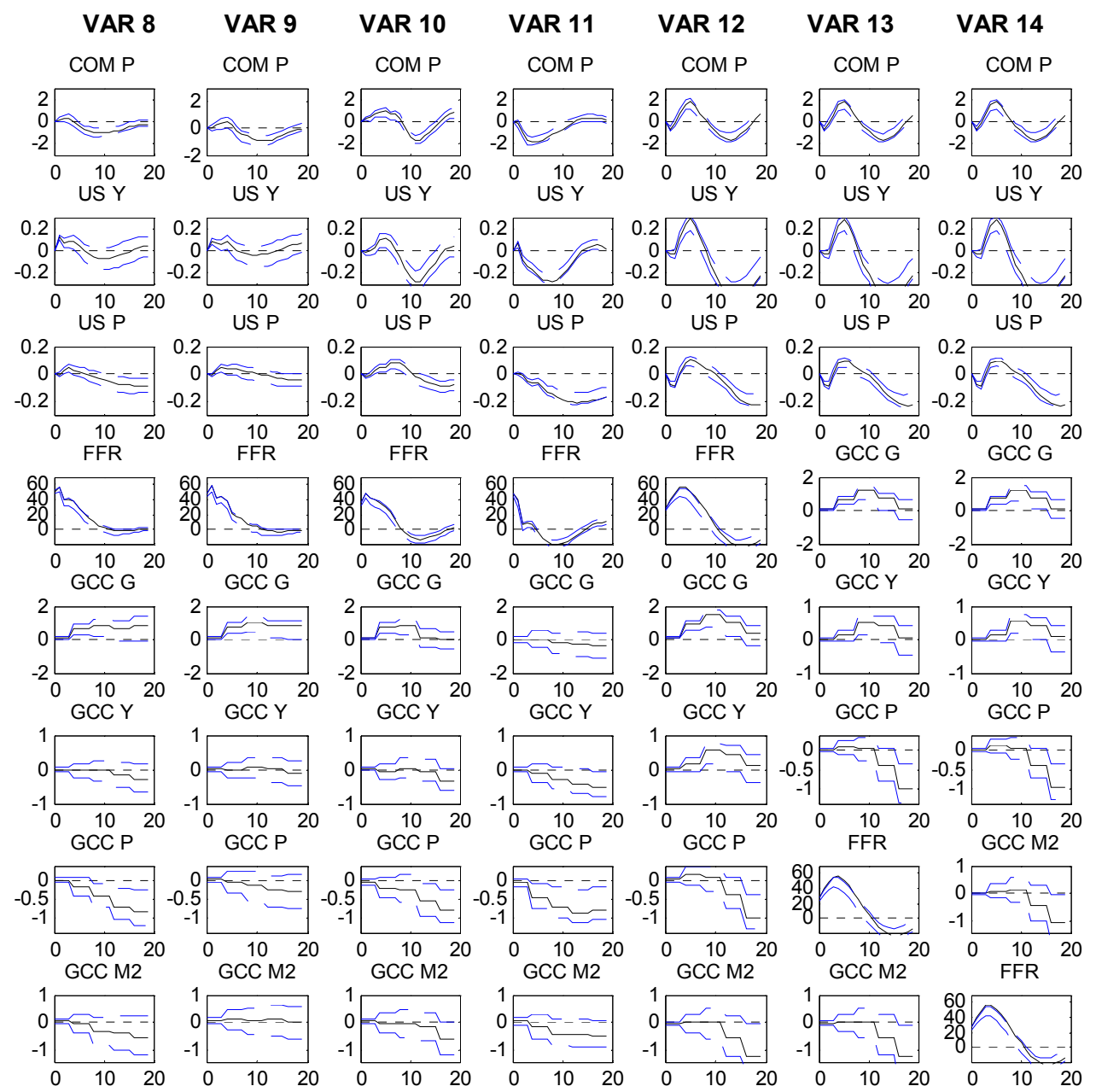

VAR 8: Baseline VAR; VAR 9: 5 lags ; VAR 10: 8 lags; VAR 11: 1980-1994 sample; VAR 12: 1995-2010 sample; VAR 13: Fed Funds Rate ordered second to last; VAR 14: Fed Funds Rate ordered last 


\section{References}

Baele, L., A. Ferrando, P. Hördahl, E. Krylova, and C. Monnet, 2004, "Measuring Financial Integration in the Euro Area," ECB Occasional Paper No. 14 (Frankfurt am Main: European Central Bank).

Boivin, J., and M. Giannoni, 2010, "Global Forces and Monetary Policy Effectiveness," in J. Galí and M. Gertler (eds.) International Dimensions of Monetary Policy, University of Chicago Press, pp. 429-488.

Bondt, Gabe de, 2002, "Retail Bank Interest Rate Pass-Through: New Evidence at the Euro Level," ECB Working Paper No. 136, April (Frankfurt am Main: European Central Bank).

Bondt, Gabe de, B. Mojon and N. Valla, 2003, "Term Structure and the Sluggishness of Retail Bank Rates in Euro Area Countries," ECB Working Paper, April (Frankfurt am Main: European Central Bank).

Bova, E., forthcoming, "Interest Rate Spread in the GCC: the Role of Monetary Policy Intervention," IMF working paper (Washington: International Monetary Fund).

Chinn, M. and G. Meredith, 2004, "Monetary Policy and Long-Horizon Uncovered Interest Parity," IMF Staff Papers 51(3): 409-430.

Christiano, L.J, M. Eichenbaum and C. L. Evans, 1999, "Monetary Policy Shocks: What Have We Learned and to What End?" Handbook of Macroeconomics, Volume 1, Part A, pp. 65-148.

Cottarelli, Carlo and Angeliki Kourelis, 1994, "Financial Structure, Bank Lending Rates, and the Transmission Mechanism of Monetary Policy," IMF Staff Papers, Vol. 41(4).

Efron, B. and R.J. Tibshirani, 1993, An Introduction to the Bootstrap (New York: Chapman \& Hall).

Espinoza, R., A. Prasad, and O. Williams, 2011, "Regional Financial Integration in the GCC," Emerging Markets Review, Vol. 12, pp. 354-370.

Espinoza, R., and A. Senhadji, 2011, "How Strong are Fiscal Multipliers in the GCC? An Empirical Investigation,” IMF Working Paper 11/61 (Washington DC: International Monetary Fund).

Hanson, M.S., 2004, “The Price Puzzle Reconsidered,” Journal of Monetary Economics, pp. $1385-1413$. 
Miniane, J., and J.H. Rogers, 2007, "Capital Controls and the International Transmission of U.S. Money Shocks," Journal of Money, Credit and Banking, pp. 1004-1035.

Mizen, P. and B. Hofmann, 2002, "Base Rate Pass-Through: Evidence from Banks' and Building Societies' Retail Rates,” Bank of England Working Paper No. 170 (London).

Prasad, Ananthakrishnan and May Khamis, 2011, "Monetary Policy and the Transmission Mechanism in the GCC Countries," in Gulf Cooperation Council Countries: Enhancing Economic Outcomes in an Uncertain Global Economy (Washington: International Monetary Fund).

Runkle, D. E., 1987, "Vector Autoregressions and Reality," Journal of Business and Economics Statistics, Vol. 5, pp.437-442.

Sander, Harald and Stefanie Kleimeier, 2004, "Convergence in Euro-Zone Retail Banking? What Interest rate Pass-Through Tells Us about Monetary Policy Transmission, Competition and Integration," Journal of International Money and Finance, Vol. 23.

Sellon Jr., G., 2002, "The Changing U.S. Financial System: Some Implications for Monetary Transmission Mechanism," Federal Reserve Bank of Kansas City Economic Review, First Quarter.

Sims, C., 1992, Interpreting the Macroeconomic Time Series Facts: The effects of Monetary Policy," European Economic Review, Vol. 36, pp. 975-1000.

Sims, C., 1998, "Comment on Glenn Rudebuschs' 'Do Measures of Monetary policy in a VAR Make Sense?”' International Economic Review, Vol.36, pp. 933-941.

Scharler, Johann, and Claudia Kwapil, 2010, "Interest Rate Pass-Through, Monetary Policy Rules, and Macroeconomic Stability," Journal of International Money and Finance, 2010, Vol. 29(2), pp. 236-251.

Zha, T., 1997, "Identifying Monetary Policy: A Primer," Federal Reserve Bank of Atlanta Economic Review, Vol. 82, pp. 26-43. 